\title{
Micro-PIXE mapping of mineral distribution in mature grain of two pearl millet cultivars
}

\author{
R. Minnis-Ndimba ${ }^{1}$, J. Kruger ${ }^{2}$, J.R.N. Taylor ${ }^{2}$, C. Mtshali ${ }^{1}$, C. A. Pineda-Vargas ${ }^{1,3}$ \\ ${ }^{1}$ iThemba LABS, National Research Foundation, South Africa. \\ 2 Department of Food Science and Institute for Food, Nutrition and Well-being, \\ University of Pretoria, South Africa \\ ${ }^{3}$ Faculty of Health and Wellness Sciences, CPUT, Bellville, South Africa
}

\begin{abstract}
Micro-proton-induced X-ray Emission (micro-PIXE) was used to map the distribution of several nutritionally important minerals found in the grain tissue of two cultivars of pearl millet (Pennisetum glaucum (L.) R. Br.). The distribution maps revealed that the predominant localisation of mineral elements was within the germ (consisting of the scutellum and embryo) and the outer grain layers (specifically the pericarp and aleurone); whilst the bulk of the endosperm tissue featured relatively low concentrations of the surveyed minerals. Within the germ, the scutellum was revealed as a major storage tissue for $\mathrm{P}$ and $\mathrm{K}$; whilst $\mathrm{Ca}, \mathrm{Mn}$ and $\mathrm{Zn}$ were more prominent within the embryo. Fe was revealed to have a distinctive distribution pattern, confined to the dorsal end of the scutellum; but was also highly concentrated in the outer grain layers. Interestingly, the hilar region was also revealed as a site of high accumulation of mineral elements, particularly for $\mathrm{S}, \mathrm{Ca}, \mathrm{Mn}, \mathrm{Fe}$ and $\mathrm{Zn}$, which may be part of a defensive strategy against infection or damage. Differences between the two cultivars, in terms of the bulk Fe and P content obtained via inductively coupled plasma optical emission spectrometry (ICPOES), concurred with the average concentration data determined from the analysis of microPIXE spectra specifically extracted from the endosperm tissue.
\end{abstract}

Keywords: Pearl millet; micro-PIXE; scutellum, mineral distribution in grains

\footnotetext{
${ }^{1} \mathrm{R}$ Minnis-Ndimba: rminnis@ $@$ tlabs.ac.za Tel +27218431165 Fax +27218433543

Materials Research Dept; ; NRF: iThemba LABS, P. O. Box 7129 Somerset West, South Africa
} 


\section{Introduction}

Mineral deficiencies adversely affect the health of more than 3 billion people worldwide [1]. This problem is particularly widespread in sub-Saharan Africa, where unfavourable socioeconomic conditions often force people to subsist on monotonous cereal-based diets that are deficient in several important micronutrients. Pearl millet (Pennisetum glaucum (L.) R. Br.) is one of the major African food security crops, which is relied upon by 90 million people as a source of food and income [2]. In terms of its overall nutritional quality (protein, starch, fat, mineral and fibre content) and anti-oxidant profile (total phenolic content and radical scavenging capacity), pearl millet grain compares well to other major cereals [3]. However, there are concerns that the amount and/or bioavailability of minerals supplied by the grain is insufficient to meet the nutritional needs of those who are most dependent on it. As a result, there is much interest in the biofortification of pearl millet, with research efforts focused on increasing the overall grain mineral content, as well as improving the bioavailability of key mineral nutrients, such as iron (Fe) and zinc ( $\mathrm{Zn})$, which are often the most limiting in the human diet [4].

The potential to breed high Fe and $\mathrm{Zn}$ biofortified pearl millet grains has been widely evaluated and confirmed [4 - 7]. To support this drive for biofortification, there is a need to understand the spatial distribution of minerals in different tissues within the grain. The mapping of minerals in seed tissues has been achieved in several notable studies, which include work on important cereals, such as wheat $[8,9]$, barley $[10]$ and rice $[11,12]$; as well as certain pseudocereals [1315] and legumes [16, 17]. To our knowledge, the only studies reporting on the spatial distribution of mineral elements in millet, include a recent study using micro-proton-induced Xray emission (micro-PIXE) for finger millet [18] and a much earlier study on pearl millet, using energy dispersive X-ray analysis (EDX) [19]. With a view to complement the previous work done on mineral distribution in millet grains, the present study was initiated, which seeks to 
interrogate differences in the mineral concentration of two cultivars of pearl millet, at the level of the main grain tissues, using micro-PIXE.

\section{Materials and Methods}

\subsection{Plant material}

Mature, dried pearl millet grains of two cultivars, namely ICMH 1201 and ICMH 1301, were kindly supplied by the International Crops Research Institute for the Semi-Arid Tropics (ICRISAT). The pearl millet cultivars were grown according to standard methods at the ICRISAT facility in India, and harvested in 2013. The cultivars were chosen because of their current use in the ICRISAT breeding programme to develop high iron and zinc pearl millet grains.

\subsection{Analysis of the bulk mineral content}

Grain samples ( $3 \mathrm{~g})$ of each cultivar were separately milled to fine (wholegrain) flour and subjected to nitric-perchloric acid digestion, according to [20], before bulk mineral content analysis by inductively coupled plasma optical emission spectrometry (ICP-OES, SPECTRO Analytical Instruments, Kleve, Germany) [21]. For each cultivar, three independent determinations of the calcium $(\mathrm{Ca})$, iron $(\mathrm{Fe})$, zinc $(\mathrm{Zn})$ and phosphorus $(\mathrm{P})$ content, were made, and the mean value $( \pm \mathrm{SD})$ reported. To evaluate differences between the means, the Student's $t$ test was performed using Statistica for Windows Version 12.6 (Statsoft Inc., USA); and differences were considered significant at $\mathrm{p}<0.05$.

\subsection{Sample preparation for micro-PIXE analysis}

Dry whole kernels from the two cultivars of pearl millet were embedded in a commercial resin (Struers EpoFix ${ }^{\mathrm{TM}}$ ) and longitudinally sectioned through the median, using a diamond-coated 
rotating blade operated at a low speed $(\sim 100 \mathrm{rpm})$, which cleanly cut the sample into half. Due to the low moisture content of the grains, no elaborate fixation procedure was deemed necessary [14]. A Nikon SMZ1500 stereomicroscope fitted with a digital camera (Nikon DS Fi2) was used to visually inspect and photograph each half-grain sample, to ensure that major anatomical features (i.e. the scutellum, embryonic axis, endosperm etc.) were clearly distinguishable in all samples selected for micro-PIXE analysis. Finally, the selected samples were coated with a thin layer of carbon before mounting in the nuclear microprobe for micro-PIXE analysis.

\subsection{Micro-PIXE analysis}

Micro-PIXE analysis was performed using the nuclear microprobe situated at the Materials Research Department, iThemba LABS [22-24]. A proton beam of $3.0 \mathrm{MeV}$ energy, a current of $\sim 100 \mathrm{pA}$ and a spot size of $3 \times 3 \mu \mathrm{m}^{2}$ was raster scanned, in two separate irradiation events, across a square-shaped area of $\sim 2 \mathrm{~mm}^{2}$ over the surface of the grain ( $\mathrm{n}=2$ per cultivar). The first scanning event covered the upper half of the grain, whilst the second scanning event was used to cover the basal half that included the entire germ tissue. Scanned areas were analysed in a square modality, using a data matrix of up to $128 \times 128$ pixels, with a total dwell time of $10 \mathrm{~ms} \mathrm{pixel}^{-1}$. X-ray spectra were detected with a PGT $\mathrm{Si}(\mathrm{Li})$ detector. Proton backscattered spectra (BS) were collected simultaneously with a surface barrier detector. A $125 \mu \mathrm{m}$ Be filter was interposed between the target and the $\mathrm{Si}(\mathrm{Li})$ detector to prevent scattered protons from reaching the detector. Following data collection, quantitative elemental maps were generated, using the Dynamic Analysis method, as part of GeoPIXE II software [25]. Additionally, micro-PIXE spectra were extracted from selected regions of interest from each sample, to obtain representative concentration data, along with the estimate of uncertainty [26], and the minimum detection limit for each element, using the Currie formula [27]. Regions of interest were selected on the basis of the major morphological features of the grain tissue [28, 29], which were readily 
distinguishable in the light micrographs and correlating micro-PIXE distribution maps. For data processing, each sample was treated as 'infinitely thick', and the main constituent of the biological matrix was assumed to be cellulose, following the approach of [30 - 32].

\section{Results and Discussion}

The bulk mineral content of the two pearl millet cultivars, as determined by ICP OES, for Ca, Fe, $\mathrm{P}$ and $\mathrm{Zn}$ is shown in Table 1 . The average content for all the minerals analysed was higher

Table 1: Total mineral contents $(\mathrm{mg} / \mathrm{kg}$ ) of the pearl millet grains, as determined by ICP-OES. Values in the same column with different superscripts differ significantly $(\mathrm{p}<0.05)$.

\begin{tabular}{lcccc}
\hline \multicolumn{1}{c}{ Cultivars } & $\mathrm{Ca}$ & $\mathrm{Fe}$ & $\mathrm{P}$ & $\mathrm{Zn}$ \\
\hline $\mathbf{1 2 0 1}$ & $72^{\mathrm{a}}(2)$ & $50^{\mathrm{a}}(1)$ & $3264^{\mathrm{a}}(102)$ & $31^{\mathrm{a}}(1)$ \\
$\mathbf{1 3 0 1}$ & $74^{\mathrm{a}}(2)$ & $55^{\mathrm{b}}(1)$ & $3731^{\mathrm{b}}(135)$ & $32^{\mathrm{a}}(1)$ \\
\hline ( ) - Values in parentheses are 1 standard deviation of 3 analyses.
\end{tabular}

in ICMH1301, however only Fe and P emerged as significantly higher $(\mathrm{p}<0.05)$ at $10 \%$ and $14 \%$, respectively. A recent study evaluating the mineral content of 225 accessions of pearl millet, revealed the following mean values (and ranges) for $\mathrm{Ca}=229.1(73.5-603.5) ; \mathrm{Fe}=42.9$ $(19.7-86.4) ; \mathrm{P}=4023.5(626.7-5705.5) ; \mathrm{Zn}=40.3(13.5-82.4) \mu \mathrm{g} . \mathrm{g}^{-1}$, respectively [7]. A comparison of these mean values with the results obtained in this study, indicate that the $\mathrm{Fe}$ content was above average in both cultivars, but levels of $\mathrm{Zn}$ and $\mathrm{Ca}$ were below average, with $\mathrm{Ca}$ distinctly at the lowest level of the range. A large range of variation in the grain mineral content of different varieties of pearl millet, is a typical observation, which may be due to the influence of both genetic and agronomic factors [7, 19]. However, the high maximum levels of Fe and $\mathrm{Zn}$ observed for some varieties [7] is demonstrative of the potential that exists within the germplasm to boost the concentration of these minerals even further. 

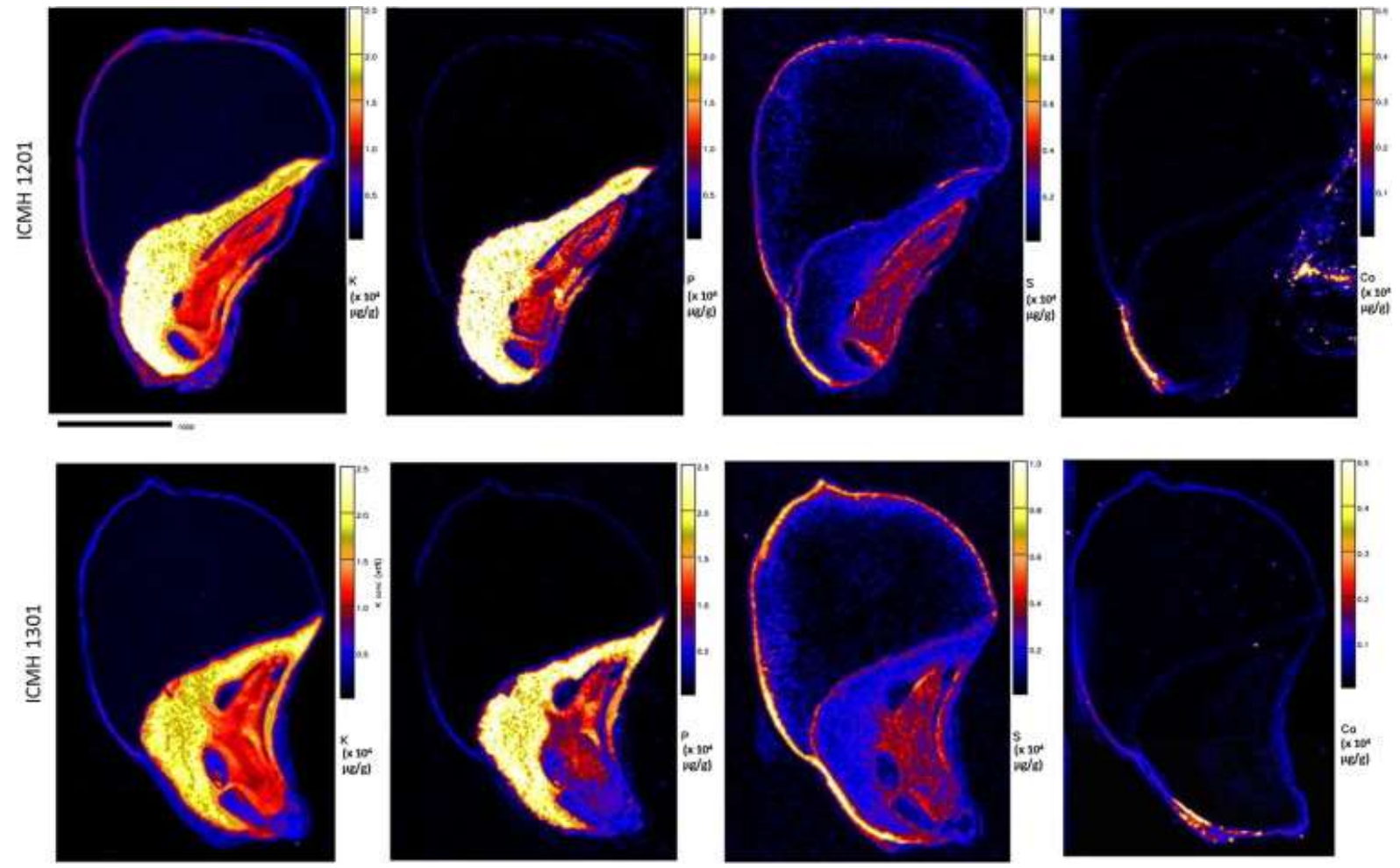

Figure 1: Quantitative spatial distribution maps of K, P, S and Ca in two cultivars of pearl millet grain, cross-sectioned longitudinally. Top row, ICMH 1201; bottom row, ICMH 1301. Colour scales represent concentrations (x $\left.10^{4} \mu \mathrm{g} \cdot \mathrm{g}^{-1}\right)$. Scale bar $=1 \mathrm{~mm}$. Note a small piece of parafilm (ICMH 1201), which is rich in Ca and P that was used to securely place the grain.

Using micro-PIXE, the spatial distribution of several minerals within the grain tissues of the two pearl millet cultivars was investigated. Quantitative elemental maps (Figs. 1 and 2) were obtained, which were further supplemented with average concentration data (Table 2), for selected grain tissues, by means of the region selection analysis tools available in the GeoPIXE software (Fig. 3). The micro-PIXE maps (Figs. 1 and 2) provided a clear visual demonstration of the non-homogenous distribution of minerals within and amongst the major grain tissues of pearl millet, which was mirrored across the two individual cultivars. This morphological distribution was mainly characterised by relatively low concentrations of the surveyed minerals in the bulk of the endosperm, whilst the outer grain layers and the germ tissue, featured high mineral concentrations. This finding confirms the well-known pattern of mineral distribution in cereal 

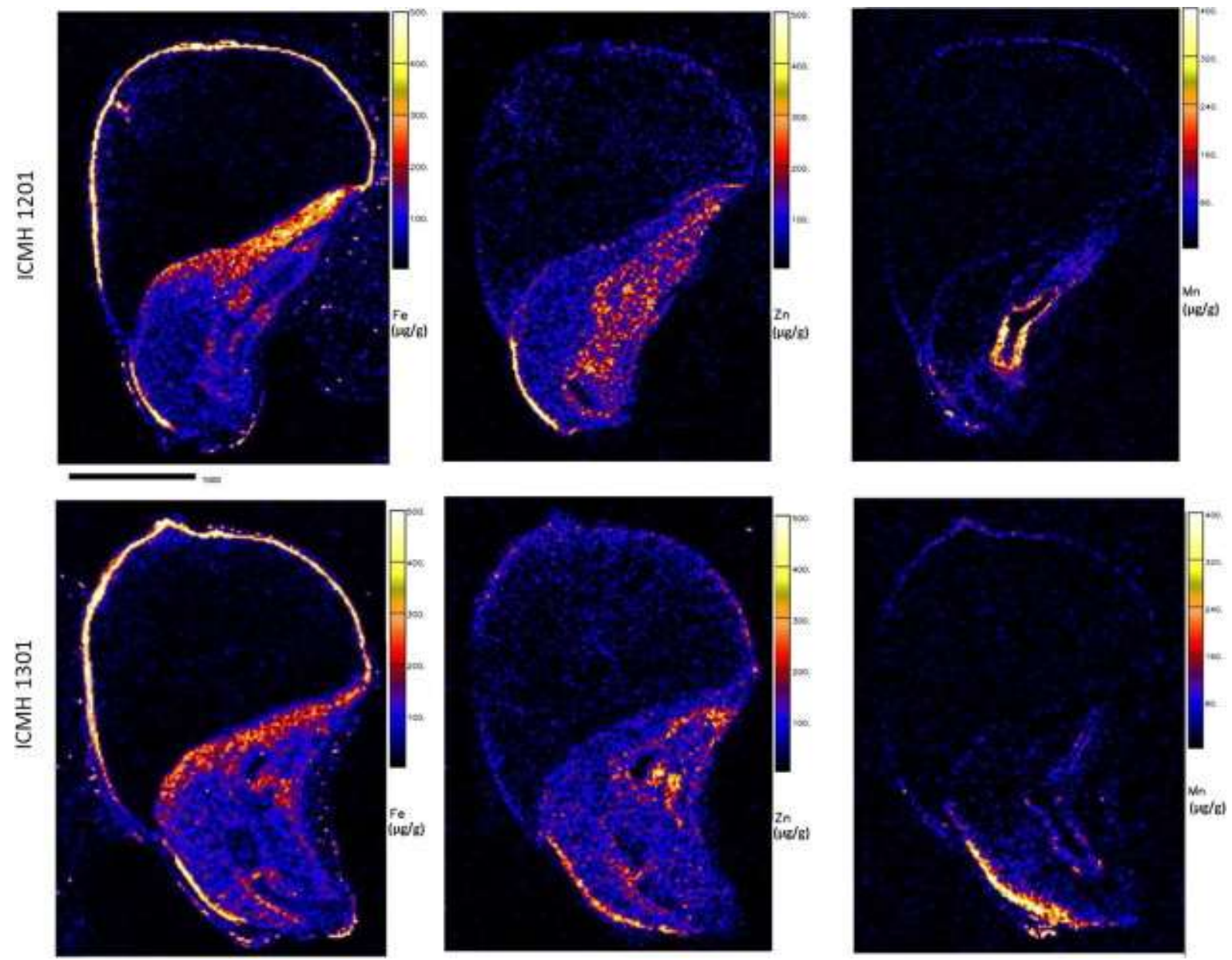

Figure 2: Quantitative spatial distribution maps of $\mathrm{Fe}, \mathrm{Zn}$ and $\mathrm{Mn}$ in two cultivars of pearl millet grain, cross-sectioned longitudinally. Top row, ICMH 1201; bottom row, ICMH 1301. Colour scales represent concentrations (x $\left.10^{4} \mu \mathrm{g} \cdot \mathrm{g}^{-1}\right)$. Scale bar $=1 \mathrm{~mm}$. Note a small piece of parafilm $(\mathrm{ICMH} \mathrm{1201)}$, which is rich in Ca and P that was used to securely place the grain.
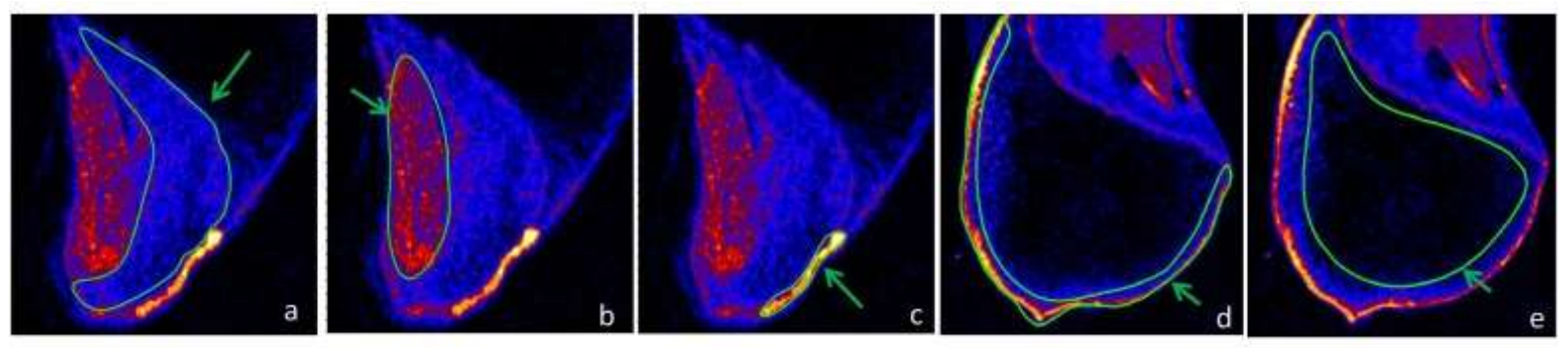

Figure 3: Examples of the regions selected for elemental quantification, based on micro-PIXE S distribution maps. The encircled regions are pointed out by the green arrow and correspond to the scutellum (a), the embryo (b), the hilar region (c), the outer grain layers (d) and the inner endosperm (e). Scale bar $=0.5 \mathrm{~mm}$. 
grains, which is typified by high concentrations of several important minerals within the socalled cereal 'bran' layers; whilst much lower concentration levels are localised within the starchy endosperm $[33,34]$.

In line with the above proposition, the most striking features of the micro-PIXE maps, were localised within the germ area of the pearl millet grains. The germ of pearl millet occupies a relatively large percentage of the total kernel $(>17 \%)$, and thus contributes significantly to the overall nutritional and mineral content of the grain $[3,35]$. Within the germ, a clear distinction in terms of the mineral concentration was observed between the two main tissue types: the scutellum and the embryo. The scutellum in particular was revealed as a major site of mineral accumulation, with the highest concentration of $\mathrm{P}$ and $\mathrm{K}$, for both cultivars, at an average of $>2.0$ $\mathrm{x} 10^{4} \mu \mathrm{g} \cdot \mathrm{g}^{-1}$ for $\mathrm{P}$, and $>1.8 \times 10^{4} \mu \mathrm{g} \cdot \mathrm{g}^{-1}$ for $\mathrm{K}$. In mature seeds, $\mathrm{P}$ is principally stored as phytic acid, which accounts for up to $80 \%$ of the total seed $\mathrm{P}$ content, and can contribute as much as $1.5 \%$ of the seed total dry weight [36]. At physiological $\mathrm{pH}$, phytic acid exists in its anionic form, and as such is able to strongly chelate cationic mineral elements, such as $\mathrm{K}, \mathrm{Mg}, \mathrm{Ca}, \mathrm{Fe}$, $\mathrm{Zn}$ and $\mathrm{Mn}$, to form phytate $[36,37]$. The most common form of phytate is as a mixed salt of $\mathrm{K}^{+}$ and $\mathrm{Mg}^{2+}$ [38], and therefore the strong co-localisation of $\mathrm{P}$ and $\mathrm{K}$ in the scutellum is likely indicative of the pervasive presence of the phytate molecule. Although certain major cereal grains like barley, wheat and rice, store most of their phytate reserves in the aleurone with little in the germ, maize exhibits a different pattern, with about $88 \%$ of its phytate stored in the germ, $2 \%$ in the endosperm, and $10 \%$ in the aleurone/outer grain layers [38]. Given the dominant levels of $\mathrm{P}$ and $\mathrm{K}$ in the germ tissues, it is clear that pearl millet is more aligned to the strategy of maize, when it comes to the preferred accumulation pattern of phytate reserves within its grain tissues. 
The next highest concentration of $\mathrm{P}$ and $\mathrm{K}$ were found within the embryo. Interestingly, although the concentration of $\mathrm{P}$ and $\mathrm{K}$ were significantly reduced ( $\sim 57 \%$ for $\mathrm{P}$; and $\sim 39 \%$ for $\mathrm{K})$ in the embryo in comparison to the scutellum, the levels of the majority of the other mineral elements were not. In fact a $>50 \%$ increase in $\mathrm{S}, \mathrm{Ca}, \mathrm{Mn}$, and $\mathrm{Zn}$ concentration was found for the pearl millet embryo tissues in comparison to the scutellum, which likely reflects the great importance of these mineral elements for the embryo's survival needs. Fe is the only mineral that demonstrates a reversal of this trend, with an average concentration that is $15 \%$ higher in the scutellum than in the embryo. Limited levels of $\mathrm{Fe}$ within the embryo may be a biological strategy aimed at protecting the embryo from Fe excess, which is linked to the production of toxic reactive oxygen species (ROS) that can lead to tissue damage by means of oxidative stress [37, 39].
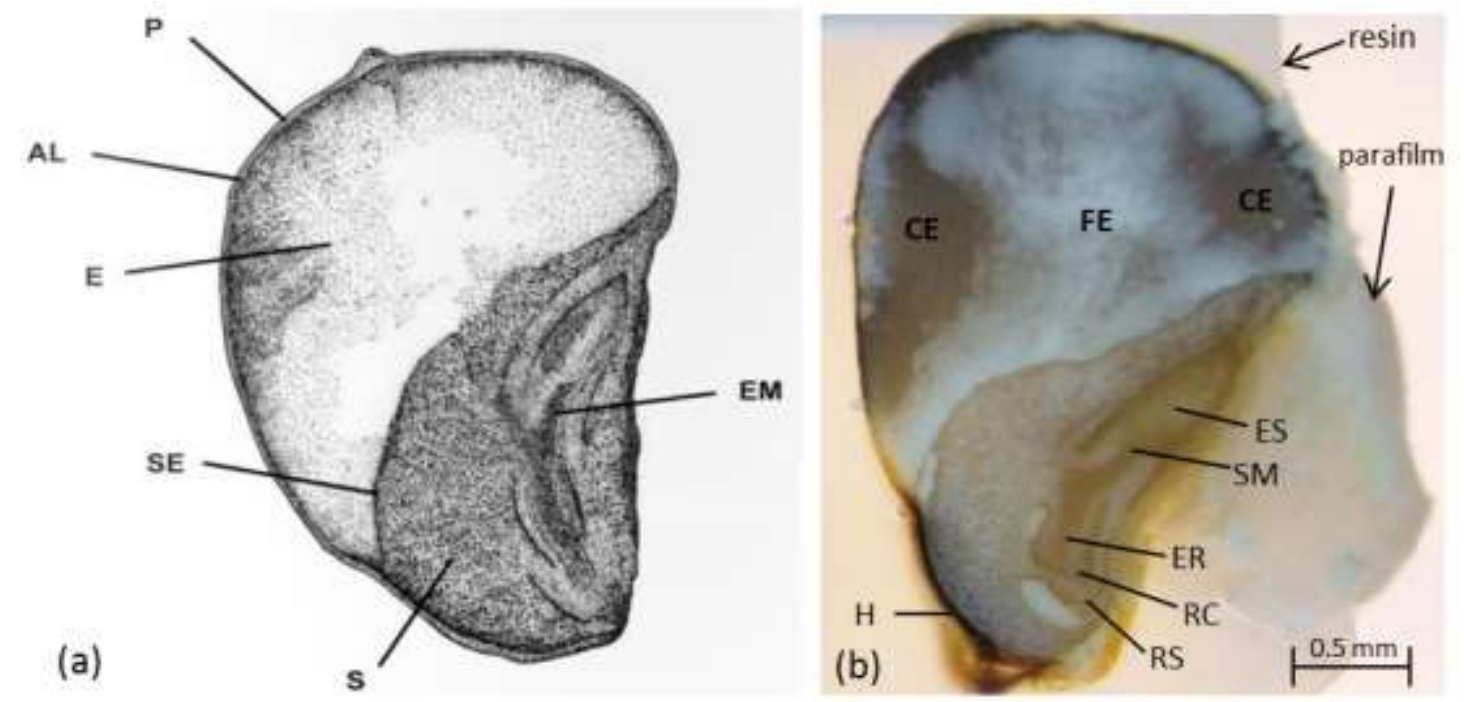

Figure 4. (a) Schematic diagram of a longitudinal median section of a pearl millet grain depicting major morphological features such as the pericarp (P), aleurone (AL), the starchy endosperm (E), scutellar epithelial cells (SE), scutellum (S) and embryo (EM) [28]. (b) Light micrograph of the dissected pearl millet grain (ICMH 1201) used for micro-PIXE analysis. Finer anatomical features such as the hilar region $(\mathrm{H})$, root cap (RC), root sheath (RS), embryonic root (ER), embryonic shoot (ES) and shoot apical meristem (SM) are pointed out, including a differentiation between the outer, more dense corneous endosperm (CE) and the inner, less dense floury endosperm (FE). Black arrows point to the 
outline of the embedding resin and to a small piece of parafilm, which was used to secure the position of the grain during resin polymerisation.

In terms of the spatial distribution of the mineral elements within the germ, varying patterns of accumulation were observed in micro-PIXE maps, which often coincided with basic aspects of the grain tissue morphology (Fig. 4). In the scutellum, fairly uniform distributions of $\mathrm{P}, \mathrm{K}$ and $\mathrm{S}$ were observed throughout this tissue, which was a pattern mirrored closely by Zn. Interestingly, the scutellar epithelial layer, which borders the scutellum and the starchy endosperm, was found to feature relatively higher concentrations of $\mathrm{S}, \mathrm{Ca}, \mathrm{Mn}$ and $\mathrm{Zn}$, which may be related to the secretory functions of this important cell layer [40]. Within the scutellum, Fe is distinguished by a unique distribution pattern, which is characterised by higher concentrations of this element accumulating specifically at the dorsal end of the scutellum, in the region closest to the border with the starchy endosperm. For the embryo tissue, very specific distribution of the various minerals was observed, which seemed to follow a clear demarcation of the different tissue types found in the embryonic region, such as the plumule, coleoptile, embryonic root, root cap and coleorhiza (rooth sheath), particularly for P, K and S. For Fe and Zn, there appears to be some common hotspots, such as at the apex of the plumule and in the tissues surrounding the shoot apical meristem and the embryonic root. Manganese however has the most distinctive pattern of distribution in the embryo that is conspicuously localised in the tissues surrounding the embryonic root, extending upwards and around what is most likely the shoot apical meristem. Interestingly, this distribution pattern for $\mathrm{Mn}$, was also observed in similar studies done on mature wheat [9] and barley grains [10]. It is speculated that this very specific localisation of Mn may be related to its known ability to inhibit the growth hormone auxin [41]. In line with the very specific localisation of $\mathrm{Mn}$, it is further noted that the most pronounced difference in concentration between the scutellum and the embryonic tissues, was observed for Mn. In 
cultivar 1301, Mn was below the detection limit $\left(<1 \mu \mathrm{g} . \mathrm{g}^{-1}\right)$ in the scutellum, but was found at an average concentration of $20 \mu \mathrm{g} \cdot \mathrm{g}^{-1}$ in the embryo, whereas in cultivar 1201, the average concentration of $\mathrm{Mn}$ in the embryo $\left(65 \mu \mathrm{g} \cdot \mathrm{g}^{-1}\right)$ was more than 7-fold greater in the scutellum of the same cultivar.

The relatively high concentrations of $\mathrm{S}, \mathrm{Ca}, \mathrm{Mn}, \mathrm{Fe}$ and $\mathrm{Zn}$ found in the germ tissues are in most cases exceeded by $>2$-fold in the grain hilar region. This region is easily identified, by its distinctive black colouration, which surrounds the outer basal region of the scutellum. During grain development, specialist transfer cells located within this region facilitate the transport of nutrients from the mother plant to the grain basal endosperm [29]. At grain maturity, darkly pigmented material accumulates to form a pigment strand, which creates an impermeable seal at this area of the grain, signalling the end of nutrient transfer from the maternal tissues $[29,42]$. It is suggested that the pigmented material is mainly composed of phenolic compounds which carry out a protective function, against disease and insect predation [29]. The high concentration of minerals in the hilar region may be reflective of this protective function, or may be indicative of structural limitations at the maternal-filial interface, which serve as a bottleneck for mineral transport into the grain $[29,43]$. Certainly, the high concentration of $\mathrm{Ca}\left(2405-3251 \mu \mathrm{g} \cdot \mathrm{g}^{-1}\right)$ is likely to play a role in maintaining cell wall integrity around this critical entry point to the grain [44]; whilst the high concentration of sulphur $\left(>6100 \mu \mathrm{g} \cdot \mathrm{g}^{-1}\right)$ is likely reflective of sulphur-rich proteins like defensins which are known to be localised around the hilar region, to protect the grain against attack by pathogenic micro-organisms and viruses [45].

Due to the low level of resolution of the micro-PIXE maps, it was not possible to definitively distinguish all the constituent layers of the outer grain tissues, (which include the pericarp, seed coat and the aleurone) therefore, these structures are broadly referred to as the outer grain layer. 
The multi-layered nature and variable thickness of the outer grain layers were perhaps most aptly reflected in the $\mathrm{K}$ distribution maps, where the presence of $\mathrm{K}$ is likely indicative of its contribution to the fortification of cell walls $[13,19]$. The cell walls of the aleurone layer are known to be particularly thick [46], and therefore regions of elevated K (> $2000 \mu \mathrm{g}^{-g^{-1}}$ ) are probably associated with the cells of this layer. As may be expected, Ca was also prominently featured within these peripheral layers, where it is likely to function in cell wall maintenance and rigidity, but also as a key regulator of certain cell-to-cell signalling processes, which are vital to the process of seed germination and growth [44]. S and Fe were also noted to be present at relatively high levels in the outer grain layers. It therefore seems plausible that $\mathrm{Fe}$ and $\mathrm{S}$ may be closely linked, particularly as part of a metalloprotein complex $[8,47]$.

Given the nutritional importance of $\mathrm{Fe}$ and $\mathrm{Zn}$, it is interesting to note that these two minerals do not share the same pattern of distribution within the pearl millet grain. Apart from the hilar region, Fe was most concentrated $\left(188-191 \mu \mathrm{g} \cdot \mathrm{g}^{-1}\right)$ in the outer grain layers. However for $\mathrm{Zn}$, the highest concentration of this mineral element was found in the embryonic tissues $(118-145$ $\mu \mathrm{g} \cdot \mathrm{g}^{-1}$ ). In all of the grain tissues investigated (apart from the hilar region), Fe was found to accumulate to higher levels in the grain of ICMH 1301 in comparison to that of ICMH 1201. This difference was most pronounced in the endosperm, where ICMH 1301 was found to have an average concentration of $11 \mu \mathrm{g} \cdot \mathrm{g}^{-1}$, which was $69 \%$ higher than the average concentration of Fe in the ICMH 1201 grain. This result confirms the average higher Fe content for ICMH 1301 that is supported by bulk analyses (Table 1), and highlights the major contribution that the endosperm tissue (which comprises $75 \%$ of the grain [35]) makes towards the overall mineral element content. A similar scenario was also evident for the concentration of $\mathrm{P}$ found in the grain endosperm by micro-PIXE (Table 2). Whereas undetectable levels of $\mathrm{P}$ were found in the endosperm of ICMH 1201, cultivar ICMH 1301 was found to have an average P concentration 
of $163 \mu \mathrm{g} \cdot \mathrm{g}^{-1}$. The low concentration of P in the endosperm of ICMH 1201 is therefore likely to be the main cause of the finding supported by bulk analyses, which showed that the bulk wholegrain P content of ICMH 1201 was significantly lower than that of ICMH 1301.

\section{Conclusion}

In this study, differences in the spatial distribution and concentration of several minerals were investigated in two cultivars of pearl millet. Using micro-PIXE, quantitative elemental mapping of $\mathrm{P}, \mathrm{K}, \mathrm{S}, \mathrm{Ca}, \mathrm{Zn}, \mathrm{Fe}$ and $\mathrm{Mn}$ in major parts of the grain was obtained. Of note, the germ and outer grain layers were found to feature relatively high concentrations of the surveyed mineral elements, whilst the bulk of the endosperm tissue featured lower concentrations. Although restricted by the low level of resolution of the micro-PIXE maps, a broad partitioning of the grain into its major constituent parts such as the scutellum, embryo, endosperm and outer grain layers allowed a preliminary investigation of the differential accumulation of minerals within these structures. In future, more detailed and precise elemental mapping may proceed on thin sections of the grain to reveal the exact cellular locations of mineral elements that were found to accumulate to high concentrations in areas of the embryo, hilum and outer grain layers. However, the information gleaned from the present study, has provided some valuable basic information on the preferential storage pattern of the investigated minerals, which will be of benefit to on-going research initiatives focused on the mineral biofortification of pearl millet grain.

\section{Acknowledgements}

Financial and technical support for this study was provided by NRF: iThemba LABS and the University of Pretoria. The pearl millet grains analysed were kindly supplied by the International 
Crops Research Institute for the Semi-Arid Tropics (ICRISAT). The digital stitching of the micro-

PIXE maps was done using Photoshop software by Dr M Khenfouch.

\section{References}

[1] R. Welch, R. Graham, J. Exp. Bot. 55 (2004) 353-364.

[2] ICRISAT, Pearl millet, a dependable and nutritious source of food for millions in marginal agricultural areas. Available from: <http://exploreit.icrisat.

org/page/pearl_millet/680>, 2015 (11.03.15).

[3] V.S. Nambiar, J.J. Dhaduk, N. Sareen, T. Shahu, R. Desai, J. Appl. Pharm. Sci. 1 (2011) 62-67.

[4] K.N. Rai, M. Govindaraj, A.S. Rao, Qual. Assur. Saf. Crops Foods 4 (2012) 119125.

[5] G. Velu, K.N. Rai, V. Muralidharan, V.N. Kulkarni, T. Longvah, T.S. Raveendran, Plant Breed. 126 (2) (2007) 182-185.

[6] M. Govindaraj, K.N. Rai, P. Sahnmugasundaram, S.L. Dwivedi, K.L. Sahtrawat, A. R. Muthaiah, A.S. Rao, Crop Sci. 53 (2013) 507-517.

[7] E.M.A. Bashir, A.M. Ali, A. Ali, A.E. Melchinger, H.K. Parzies, B.I.G. Haussmann, Plant Genet. Resources 12 (1) (2014) 35-47.

[8] S.P. Singh, K. Vogel-Mikuš, I. Arčon, P. Vavpetič, L. Jeromel, P. Pelicon, J. Kumar, R. Tuli, J. Exp. Bot. 64 (2013) 3249-3260.

[9] A.P. Mazzolini, C.K. Pallaghy, G.J.F. Legge, New Phytol. 100 (1985) 483-509.

[10] E. Lombi, E. Smith, T.H. Hansen, D. Paterson, M.D. de Jonge, D.L. Howard, D.P.

Persson, S. Husted, C. Ryan, J.K. Schjoerring, J. Exp. Bot. 62 (2011) 273-282.

[11] L. Lu, S. Tian, H. Liao, J. Zhang, X. Yang, J.M. Labavitch, W. Chen, PLoS ONE 8 (2)

(2013) e57360, http://dx.doi.org/10.1371/journal.pone.0057360.

[12] E. Lombi, K.G. Scheckel, J. Pallon, A.M. Carey, Y.G. Zhu, A.A. Meharg, New Phytol. 184 (2009) 193-201.

[13] Y. Konishi, S. Hirano, H. Tsuboi, M. Wada, Biosci. Biotechnol. Biochem. 68 (1) (2004) 231-234.

[14] K. Vogel-Mikuš, P. Pelicon, P. Vavpetič , I. Kreft, M. Regvar, Nucl. Instr. Meth. Phys. Res. B 267 (2009) 2884-2889.

[15] P. Pongrac, K. Vogel-Mikuš, L. Jeromel, P. Vavpetič, P. Pelicon, B. Kaulich, A.

Gianoncelli, D. Eichert, M. Regvar, I. Kreft, Food Res. Int. 54 (2013) 125131.

[16] C. Cvitanich, W.J. Przybyłowicz, D.F. Urbanski, A.M. Jurkiewicz, J. MesjaszPrzybyłowicz, M.W. Blair, C. Astudillo, E.Ø. Jensen, J. Stugaard, BMC Plant Biol. 10 (2010) 26-39.

[17] C. Cvitanich, W.J. Przybyłowicz, J. Mesjasz-Przybyłowicz, M.W. Blair, C. Astudillo, E. Orłowska, J. Stougaard, Nucl. Instr. Meth. B 269 (2011) 22972302.

[18] J. Kruger, C.A. Pineda-Vargas, R. Minnis-Ndimba, J.R.N. Taylor, J. Cereal Sci. 60 (2014) 1-3.

[19] E. Varriano-Marston, R.C. Hoseney, Cereal Chem. 57 (2) (1980) 150-152.

[20] R.J. Zasoski, R.G. Burau, Commun. Soil Sci. Plant Anal. 8 (1977) 425-436.

[21] J. Kruger, J.R.N. Taylor, A. Oelofse, Food Chem. 131 (2012) 220-224.

[22] V.M. Prozesky, W.J. Przybylowicz, E. van Achterbergh, C.L. Churms, C.A. Pineda, 
K.A. Springhorn, J.V. Pilcher, C.G. Ryan, J. Kritzinger, H. Schmitt, T. Swart, Nucl. Instr. Meth. B 104 (1995) 36-42.

[23] W.J. Przybylowicz, J. Mesjasz-Przybylowicz, C.A. Pineda, C.L. Churms, K.A. Springhorn, V.M. Prozesky, X-ray Spectrom. 28 (1999) 237-243.

[24] W.J. Przybylowicz, J. Mesjasz-Przybylowicz, C.A. Pineda, C.L. Churms, C.G. Ryan, V.M. Prozesky, R. Frei, J.P. Slabbert, J. Padayachee, W.U. Reimold, X-ray Spectrom. 30 (2001) 156-163.

[25] C.G. Ryan, J. Imaging Syst. Technol. 11 (2000) 219-230.

[26] C.G. Ryan, D.R. Cousens, S.H. Sie, W.L. Griffin, G.F. Suter, E. Clayton, Nucl. Instr. Meth. Phys. Res. B 47 (1990) 55-71.

[27] L.A. Currie, Anal. Chem. 40 (1968) 586-593.

[28] J.A. Delcour, R.C. Hoseney, Principles of Cereal Science and Technology, 3rd ed., AACC International, St Paul, MN, 2010.

[29] L.K. Fussell, D.M. Dwarte, J. Exp. Bot. 31 (121) (1980) 645-654.

[30] E.T.F. Witkowski, I.M. Weiersbye-Witkowski, W.J. Przybylowicz, J. Mesjasz-

Przybylowicz, Nucl. Instr. Meth. Phys. Res. B 130 (1997) 381-387.

[31] W.J. Przybylowicz, C.A. Pineda, A.D. Barnabas, J. Mesjasz-Przybylowicz, Nucl. Instr. Meth. Phys. Res. B 150 (1999) 282-290.

[32] C.A. Pineda, M. Peisach, Nucl. Instr. Meth. Phys. Res. B 35 (1988) 344-348.

[33] B. Kryiacou, K.L. Moore, D. Paterson, M.D. de Jonge, D.L. Howard, J. Stangoulis, M. Tester, E. Lombi, A.T. Johnson, J. Cereal Sci. 59 (2014) 173-180.

[34] P. Pongrac, I. Kreft, K. Vogel-Mikuš, M. Regvar, M. Germ, P. Vavpetic`, N. Grlj, L. Jeromel, D. Eichert, B. Budič, P. Pelicon, J. R. Soc. Interface 10 (2013)

20130296, http://dx.doi.org/10.1098/rsif.2013.0296.

[35] A. Abdelrahman, R.C. Hoseney, E. Varriano-Maston, J. Cereal Sci. 2 (1984) 127133.

[36] L. Bohn, A.S. Meyer, S.K. Rasmussen, J. Zhejiang Univ. Sci. B 9 (3) (2008) 165191.

[37] I. Kranner, L. Colville, Environ. Exp. Bot. 72 (2011) 93-105.

[38] J.C. Liu, I. Ockenden, M. Truax, J.N.A. Lott, Seed Sci. Res. 14 (2004) 109-116.

[39] H. Roschzttardtz, G. Conéjéro, F. Divol, C. Alcon, J.-L. Verdeil, C. Curie, S. Mari, Front. Plant Sci. 4 (2013) 1-11 (article 350).

[40] H. Tnani, N. García-Muniz, C.M. Vicient, I. López-Ribera, J. Plant Physiol. 169

(14) (2012) 1430-1433.

[41] C.D. Foy, R.L. Chaney, M.C. White, Annu. Rev. Plant Physiol. 29 (1) (1978) 511566.

[42] N. Aoki, T. Hirose, S. Takahashi, K. Ono, K. Ishimaru, R. Ohsugi, Plant Cell Physiol. 40 (1999) 1072-1078.

[43] S.Y. Zee, T.P. O’Brien, Aust. J. Biol. Sci. 24 (1971) 391-395.

[44] P.K. Hepler, Plant Cell 17 (2005) 2142-2155.

[45] M. Balandín, J. Royo, E. Gómez, L.M. Muniz, A. Molina, G. Hueros, Plant Mol. Biol. 58 (2005) 269-282.

[46] L. Taiz, E. Zeiger, Plant Physiology, Sinauer AssociateS Inc, Sunderland, MA, 2002.

[47] D. Steinfurth, C. Zörb, F. Braukmann, K.H. Mühling, J. Plant Physiol. 169 (2012) $72-77$. 